\title{
AN ARC MELTING SYSTEM WITH A NON-CONTACT IGNITION
}

\begin{abstract}
Arc melting is a widely used method in materials physics, in general in materials science, as well as in metallurgy, to synthesize new materials starting from high purity constituents. As the high temperature of the technological process is easily attainable, typically arc melting is used to synthesize new materials from metals, and even oxides, with high melting points. In the melting methods usually used the arc is ignited by briefly touching the electrode to the crucible and quickly withdrawing it to a short distance. The contact ignition, however, can contaminate the tip of the tungsten electrode and consequently can reduce the purity of the obtained ingot as compared to the initial components. In order to avoid the contact procedure and thus the purity reduction, an arc non-contact ignition system for melting is proposed in this paper. The arc melting system, the furnace design, the ready for use arc furnace, and the melting procedure, are presented and discussed. Additionally, an arc furnace with a suction attachment to prepare ingots as rods is presented. The clean crystal structures, known from literature, were determined for a number of the compounds synthesized by the non-contact arc method. This quality of crystal structures results mainly from the maintained materials purity during synthesis.
\end{abstract}

Keywords: arc, melting system, non-contact ignition, furnace design, synthesis procedure, suction attachment, materials purity

\section{INTRODUCTION}

The preparation of high-purity metallic alloys or compounds in materials science, materials physics, electronics, metallurgy, is constantly determining challenges for the synthesis procedure [1,2]. The idea is not to reduce the purity of the synthesized material when compared to the purity of the starting constituents. In this respect, materials synthesis by using the arc melting technique is step by step improved. [3-6].

Typically, the widely used arc furnaces consist of a chamber housing an electrically insulated tungsten electrode and a copper hearth (crucible) upon which

1 Marek Onak, Tarnów Center for Practical and Continuing Education, ul. Szujskiego 13, 33-100 Tarnów, Poland

2 Autor do korespondencji/corresponding author: Jarosław Pszczoła, Faculty of Mathematics and Applied Physics, Rzeszów University of Technology, al. Powstańców Warszawy 12, 35-959 Rzeszów, e-mail: j.pszczola@prz.edu.pl 
the sample is melted [1,2]. The DC (direct current) arc is initiated by electrical contact between the tungsten electrode tip and the copper hearth. The hearth is internally water cooled and thus the container/melt reaction and consequently the melt contamination is excluded even with the highest melting point metals. Nevertheless, the so-called non-consumable tungsten electrode contaminates the melt with materials of this electrode and the crucible as a result of the contact ignition.

Fortunately, the development of the TIG (abbreviation: tungsten inert gas) welding method enables one to also overcome this difficulty. In this case, the inverter welder with the HF (high frequency) non-contact arc ignition as a power supply for the arc system can be applied [4]. An arc melting system using this power solution in order to omit the contact ignition of the arc during the melting procedure is proposed in the present paper.

\section{THE ARC MELTING SYSTEM}

The arc melting system with non-contact ignition applied to materials synthesis has been developed (Figs 1,2). The arc melting furnace (1) is surrounded by the supplementary elements: the lamp or a non-contact temperature meter (2), the inert gas system (3), the power supply unit (4), and the vacuum pump (5).

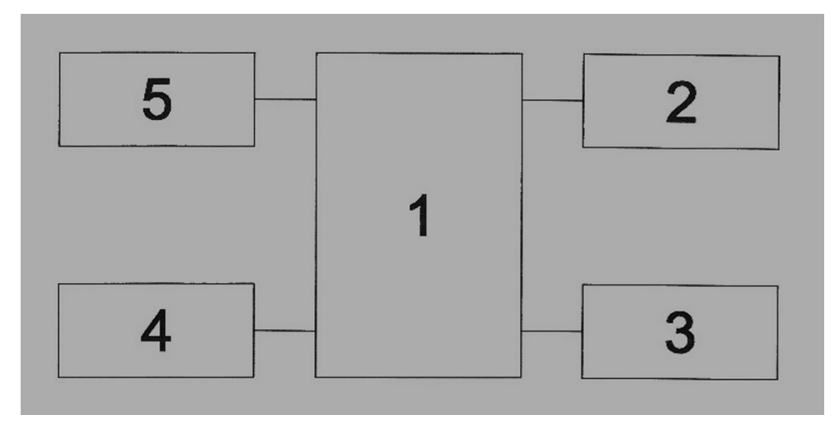

Fig. 1. Scheme of the arc melting system with non-contact ignition composed of: arc furnace (1), lamp (2), inert gas system (3), power supply (4) and vacuum pump (5)

The lamp (2) is sometimes used to light up inside the melting chamber in order to inspect through the other window the starting constituents before melting. The inert gas system (3) is composed of a steel bottle, the container of high purity argon gas, under a pressure 200-300 bar. Before using the shielding gas the high pressure must be reduced to a suitable working pressure. The next necessary component of the system is therefore a pressure-reducing valve with a gauge where the current pressure of the outflow gas can be read. The inert gas is 
introduced to the melting chamber of the arc furnace through the blocking valve attended by the pressure meter, which is attached to the melting chamber. The power unit supply (4) is the typical inverter TIG welder [4] equipped with a high frequency facility for ignition of the arc. In the power unit supply inverter technology is used [7-10]. Namely, in the inverter the power supply from a standard $50 \mathrm{~Hz}$ electrical current from the electric grid is used. However, instead of being fed directly into a transformer (as in the old welder version), it is first rectified to $50 \mathrm{~Hz}$ DC.

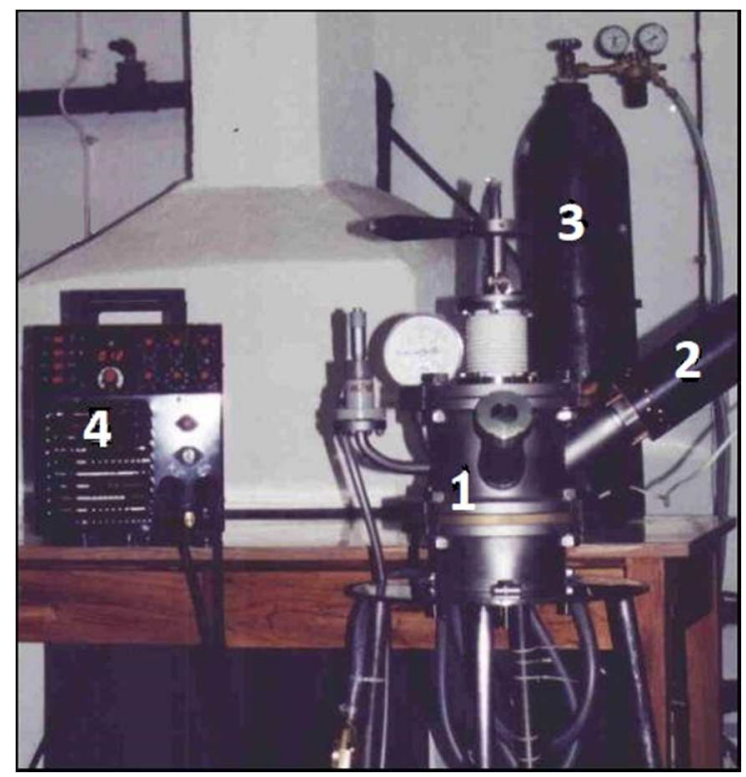

Fig. 2. Arc melting system with non-contact ignition: arc furnace (1), lamp (2), inert gas system (3), power supply (4) and vacuum pump (5) - not presented

The current is then fed into the inverter section of the power supply where it is switched on and off by solid state switches at frequencies as high as $20000 \mathrm{~Hz}$. Subsequently, this pulsed, high voltage, high frequency, DC is fed to the main power transformer, where it is transformed into a low voltage $20000 \mathrm{~Hz}$ DC suitable for welding or melting. Finally it is put through a filtering and rectifying circuit. Output control is performed by solid state controls which modulate the switching rate of the switching transistors. The main power transformer, which operates at $20000 \mathrm{~Hz}$ is vastly more efficient than $50 \mathrm{~Hz}$ transformers, which means that it is much smaller and thus the weight and dimensions of the welder are distinctly reduced. As a rule, the TIG welder supplies are equipped with an ignition facility. This facility is a high frequency unit (HF) which increases the frequency to 2-4 million periods per second and the voltage to several thousand 
volts. These parameters are suitable to strike a spark between the tungsten electrode and the crucible with the charge, to create a conductive path through the shielding gas, and thus to strike the melting arc. The vacuum pump (5) is composed of the rotary and the diffusion units as well as the vacuum meters. The outlet of the vacuum pump is connected to the exhaust ventilation system in order to remove the pollution which can appear from the melting chamber during the melting process.

\section{THE MELTING CHAMBER}

The new construction of melting chamber with the non-contact arc ignition, and thus with non contact melting was designed (Fig. 3). At the bottom of the figure the cooler (1) made of stainless steel is presented. Inside of the cooler the water flow distributor (2) is located. The water inlet (26) and the water outlet (27) are welded to the cooler. The cooling water is directed by the flow distributor (2) onto the lower surface of the crucible housing (3) which is made of brass. On the front of the crucible housing the replaceable cold crucible (4) with a hollow for a charge is mounted. It is possible to use crucibles with hollows of different shapes. In the hollow of the cold crucible the starting materials to be synthesized (charge) are placed before melting. The cold crucible (4) also composes the positive electrode of the furnace electrical system. The contact of the cooler (1) and the crucible housing (3) are sealed by the rubber o-ring (5).

The melting chamber (6) is mounted on the crucible housing (3). These two parts (6 and 3) are easily held together by the thick screw joints (23) attached to the side cuttings in the flanges (the fast fittings, see Fig. 2). The melting chamber (6) is equipped with the window system that is the sight glass (8) which can be used for inspection of the melting process, or to fix a lamp or to fix the non-contact temperature control system. Similar sight-glass is located in the front of the melting chamber (6). Terminals for the vacuum pump (10), for the pressure meter (20, terminal not visible), for the inert gas inlet $(21,22)$ and for the safety valve (25) are present on the melting chamber sides. The melting chamber (6) is covered with the chamber lid (11).

The essential part for the non-contact arc ignition is composed of several elements (Fig. 4). Namely, in the central part at the bottom surface of the lid (11) the sliding rings (13) made of teflon are attached by the holding ring (24). These sliding rings fix the placement of the ball guide (14), also made of teflon. Use of the electrically isolating teflon for these elements enables the non-contact melting in the arc furnace. These teflon elements $(13,14)$ with well-chosen dimensions, as well as the teflon bellows (15), exclude a parasitical arc between the electrode tube (12) and the chamber lid (11). Here it can be added that as a rule in the contact ignition arc systems stainless steel bellows and phosphor bronze balls are used [1, $2]$. The non-contact ignition melting procedure excludes this solution. 
The ball guide (14) is pressed indirectly to the chamber lid (11) by the holding ring (24). The electrode tube (12) that is the handle of the tungsten end electrode (7) can move throughout the ball guide (14). The electrode tube (12) and the tungsten end electrode (7) form the negative electrode of the furnace electrical system. The electrode tube (12) is equipped with a welded flange which covers the top of the teflon bellows (15) in a vacuum tight manner. The divided ring (19) clamps the bellows (15) to the flange. Similar rings fix the bellows (15) to the chamber lid (11).

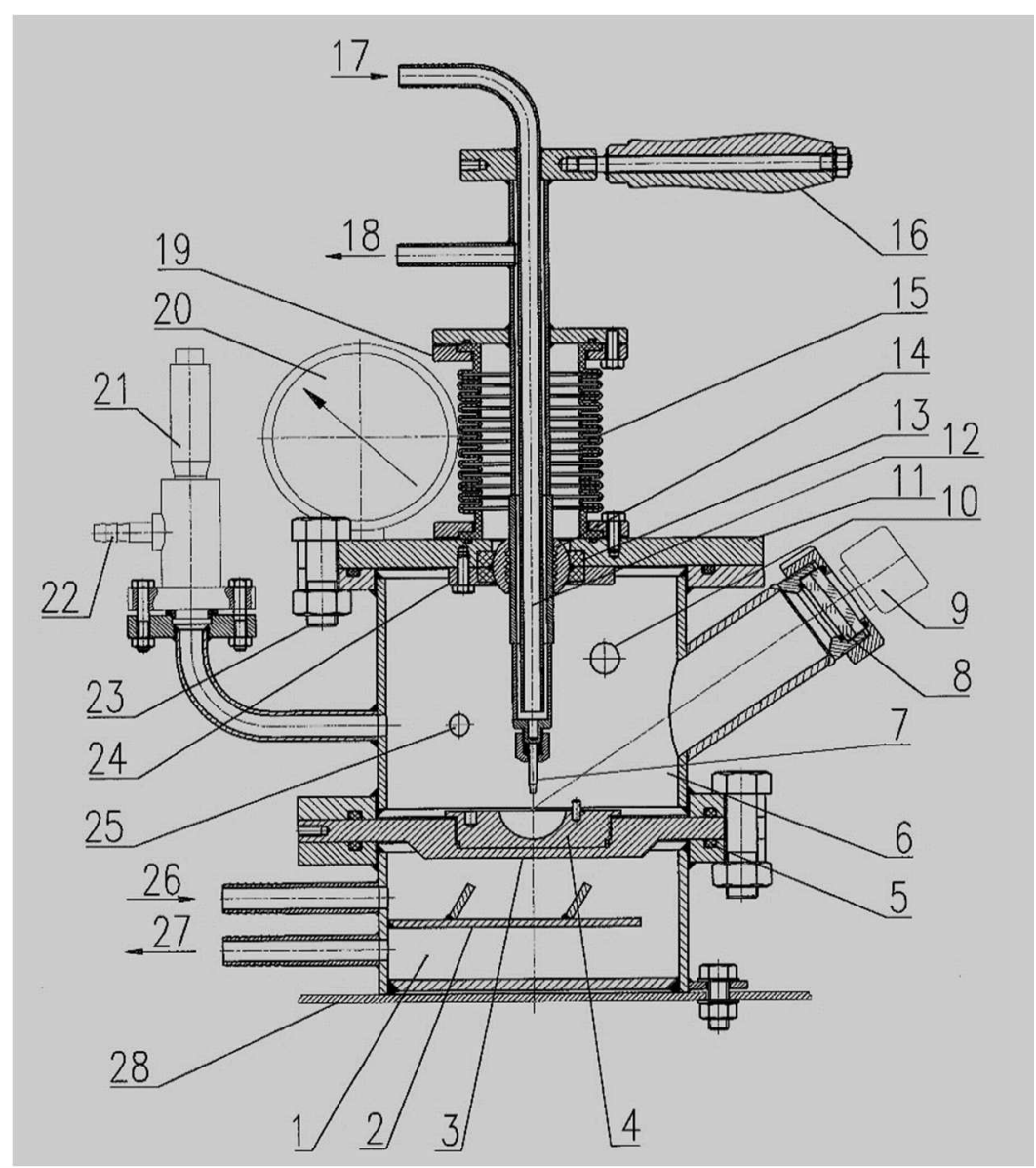

Fig. 3. Design of the main part of the electrical arc furnace devised for the noncontact arc ignition. Components numbered 1-28 are as follows: 1 - cooler, 2 - flow distributor, 3 - crucible housing, 4 - cold crucible, 5 - O-ring, 6 - melting chamber, 7 - tungsten end electrode, 8 - window, 9 - lamp, 10-connection to vacuum pump, 11 - chamber lid, 12 - electrode tube, 13 - sliding rings, 14 - ball, 15 - bellows, 16 handle, 17 - water inlet, 18 - water outlet, 19 - divided ring, 20 - pressure meter, 21 - metering valve, 22 - inert gas inlet, 23 - screw joint, 24 - holding ring, 25 - connection to safety valve, 26 - water inlet, 27 - water outlet, 28 - supporting table 


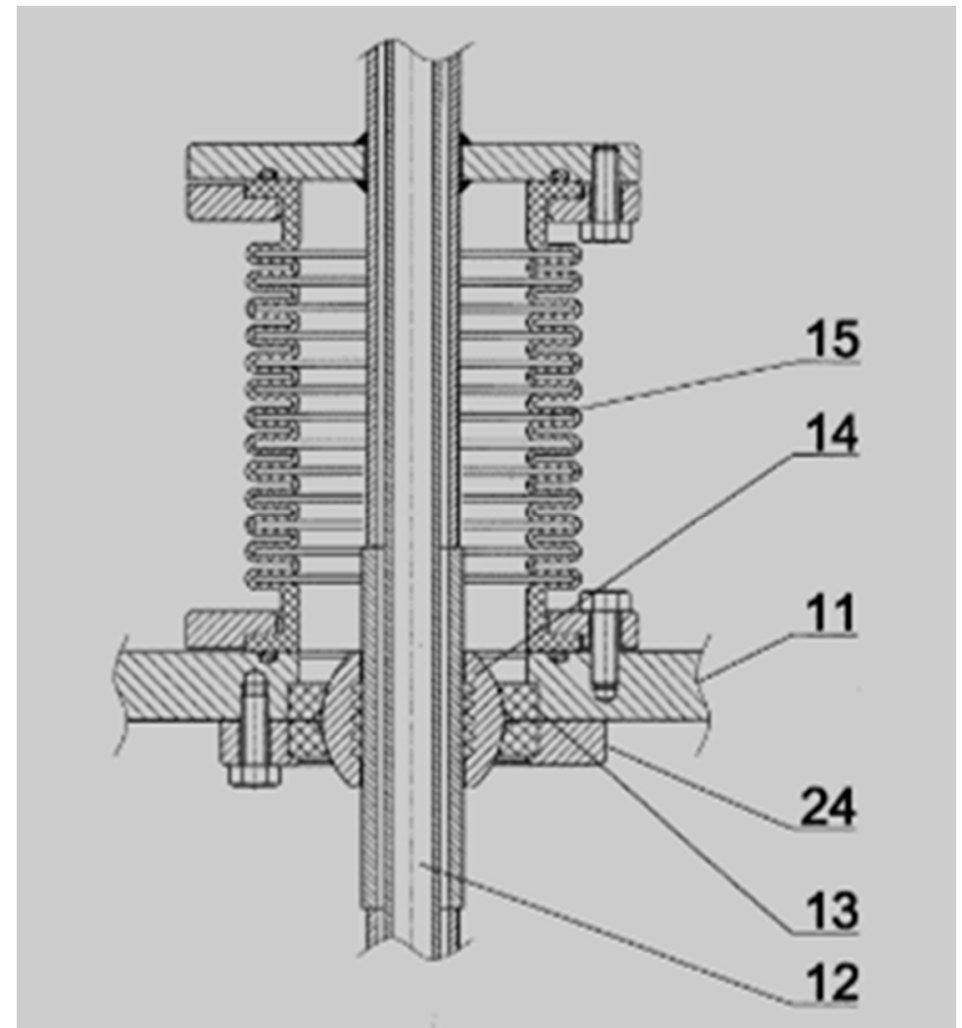

Fig. 4. A cross section of the part essential for the non-contact ignition composed of the bellows made of teflon (15), the electrode tube made of stainless steel/copper (12), the guide ball made of teflon (14), the sliding rings made of teflon (13), the holding ring made of stainless steel (24), the lid made of stainless steel (11), and the divided ring (19)

The teflon bellows (15), the ball guide (14), and the sliding rings (13) electrically isolate the negative electrode tube (12) as well as the tungsten end electrode (7) from the chamber lid and thus from the rest of the furnace, including the positive electrode (4).

The upper part of the electrode tube is equipped with electrically isolating handles (16) with acorn nuts, all made of teflon.

The handles (16), the bellows (15), and the ball guide (14) enable both the displacement of the electrode (7) and its deviation from the vertical.

The water inlet (17) and the water outlet (18) connected to the electrode tube (12), which is concentrically double tubed, form the water cooling system of the negative tungsten end electrode (7). The complete furnace is mounted on a supporting table (28). 


\section{THE BASIC SYNTHESIS PROCEDURE}

The high temperature synthesis procedure using the arc melting system with non-contact ignition is a simple and convenient method. After introducing the components to be melted into the hollow of the cold crucible (4), the melting chamber (6) is covered with the chamber lid (11). The distance between the tungsten end electrode (7) and the charge in the crucible (4) is then approximately equal to $10-15 \mathrm{~mm}$.

As a next step, the distance muff with a semicircle C-letter type cross section made of polyamide is interposed between the chamber lid (11) and the flange of the electrode tube (12) (Figs 2, 3). The distance muff precludes an excessive compression of the bellows (15), and thus precludes a shift of the end tungsten electrode (7) into the charge during the pumping procedure. Subsequently, air is evacuated from the melting chamber (6) and also from the bellows (15) using the vacuum pump system. After attaining the required vacuum level the connection to the pump (10) is closed and the melting chamber (6) is filled up with the high purity argon gas from the inert gas system. In order to remove the rest of the oxygen the pumping and the argon lavage is repeated several times. Usually, the melting chamber (6) is filled up with argon up to atmospheric pressure or slightly higher, which is controlled by the pressure meter (20).

Argon, an inert gas, cannot react with the other elements during the melting process. Moreover, this shielding gas plays an important role in connection with the transfer of current and heat in the arc. After almost filling up with argon, the distance muff is removed and the mobility of the electrode tube system $(7,12,15,16)$ is recovered. Afterwards, the cooling water system is included $(17,18)$, the high frequency tungsten inert gas (TIG) power supply is switched on and the arc, ignited in the non-contact manner inside the melting chamber (6), begins to work. It should be emphasized that this pilot arc does not do any melting, but it is needed to start the proper melting arc without touching the tungsten electrode to the crucible. Inert gas atoms are ionized by losing electrons and leaving a positive electric charge. Then the gas ions flow to the negative pole (tungsten electrode) and the negative electrons flow to the positive pole (crucible with charge). This is the so-called electrode negative polarity melting procedure. Reverse polarity can also be used, however in this case the current carrying capacity of the tungsten electrode is extremely low. Moreover, small fragments of the charge are launched from the crucible by this sort of arc.

The non-contact arc melting procedure is presented in Fig. 5. The working arc inside the chamber illuminates the window (Fig. 5-1). The glowing arc occuring between the tungsten end electrode and the distanced from it cold crucible melts the sample (Fig. 5-2). The tungsten end electrode, the cold crucible, and the synthesized drop, as they are after the arc is switched off, are presented in Fig. 53 ; the considerable distance is visible. The result of the melting procedure, the solidified drop inside the opened melting chamber is shown in Fig. 5-4. 

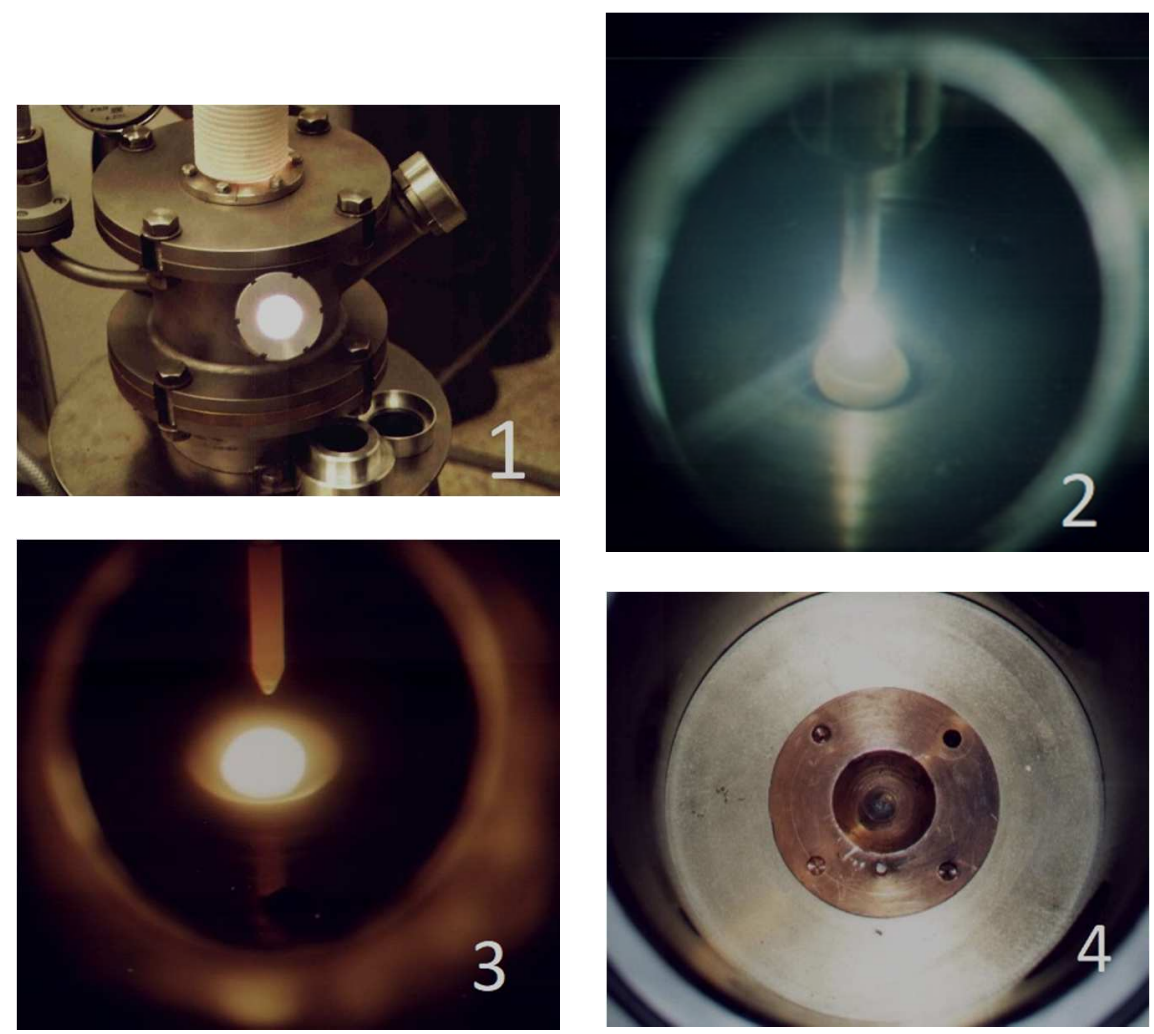

Fig. 5. The non-contact arc melting is switched on $(1,2)-$ ultraviolet radiation prevails, the synthesized drop after the arc is switched off (3) - red radiation prevails and the solidified drop inside the opened melting chamber (4)

\section{THE TUNGSTEN END ELECTRODE}

The fundamentally important tungsten end electrode is prepared from rods of pure tungsten metal. Tungsten is a metal with both and extremely high melting point, $3695 \mathrm{~K}$, and boiling point, $6203 \mathrm{~K}$. Thus the tungsten melting and boiling points are more than double as compared to the melting and boiling points of iron (1811K and $3134 \mathrm{~K}$ respectively), cobalt $(1768 \mathrm{~K}$ and $3200 \mathrm{~K})$ or nickel $(1728 \mathrm{~K}$ and $3003 \mathrm{~K}$ ). Therefore the tungsten electrodes are treated as standards in the TIG welding and arc melting procedures.

Nevertheless, alloying the tungsten with a few per cent of certain metal oxides $\left(\mathrm{ThO}_{2}, \mathrm{ZrO}_{2}, \mathrm{LuO}_{2}, \mathrm{CeO}_{2}\right)$ improves the electrode properties. Thorium oxide especially is predicted to improve the electrodes for the TIG welding method. However, the tungsten electrodes with the addition of the thorium oxide are slightly alpha-radioactive and thus inhalation of ground thorium dust, smoke containing thorium, or fumes containing thorium, is hazardous for health. Evidently, these thorium content pollutants radioactively contaminate the 
environment. Therefore the use of thorium electrodes (in market marked with red colour) during the arc melting procedure in the arc furnaces should be definitely refused.

There is a relationship between the electrode and the melting (welding) arc. Namely, parameters of the arc depend to some extent on the dimensions, end shape and the grinding of the electrode [7-10]. The diameter of the electrode should be adjusted for the current intensity. When welding is done with a direct current and the electrode polarity is negative, the electrode point should be conical in order to obtain a concentrated arc that will provide a narrow and deep penetration profile. A small pointed angle gives a narrow weld pool and the larger pointed angle gives the wider weld pool. Blunting the electrode point to make a flat area can increase the lifetime of the tungsten electrode. Additionally for the welding procedure the grinding traces for the electrode point should lie along the electrode in order to obtain a narrow weld pool.

These restrictions are not necessarily suitable for the arc melting process. Namely, often a wide arc is necessary to perform an efficient melting process. In this case, the flattened electrode point or even the electrode with a half globular form extends the arc wide. Moreover, circular grindings of the electrode point introduce an umbrella-like shape to the arc. The hemispherical cavity inside the cold crucible (4) (Fig.3) stabilizes the umbrella-like shape of the melting arc. This shape of the arc is advantageous for the melting procedure. As a result of not too large a travel down the electrode tube (12) with the tungsten end electrode (7) the umbrella-like arc pushes the charge in the crucible and melts it as a whole almost immediately. A standard type arc also can melt the charge. This arc can be directed throughout the charge by using the handles (16) to melt all the charge constituents together.

\section{FURNACE WITH THE SUCTION CHAMBER}

Figure 6 presents the version of the arc melting furnace with the system designed to prepare rods from the melt. The upper part of the furnace is identical to the basic version (Fig. 3), but different numbers are used to identify particular components. Nonetheless the construction of the lower part of the furnace is considerably different. In this case, the crucible housing that is the suction chamber (3), equipped with the connection to the vacuum pump (31), is mounted to the cooler (1). This cooler is without the flow distributor. The main plate of the cold crucible (4) is settled on the cooler (1) whereas its central conical part connects by lower tailpiece with the crucible housing (3). Inside of the cold crucible (4) the divided cold crucible (5) is fixed by the clamp ring (7). The charge to be melted is placed inside of the hollow of the divided crucible (5).

The arc furnace, with the cooler (1) situated directly above the circular table (30) and the suction chamber (3) situated directly under the circular table (30), is presented in Fig. 7. 


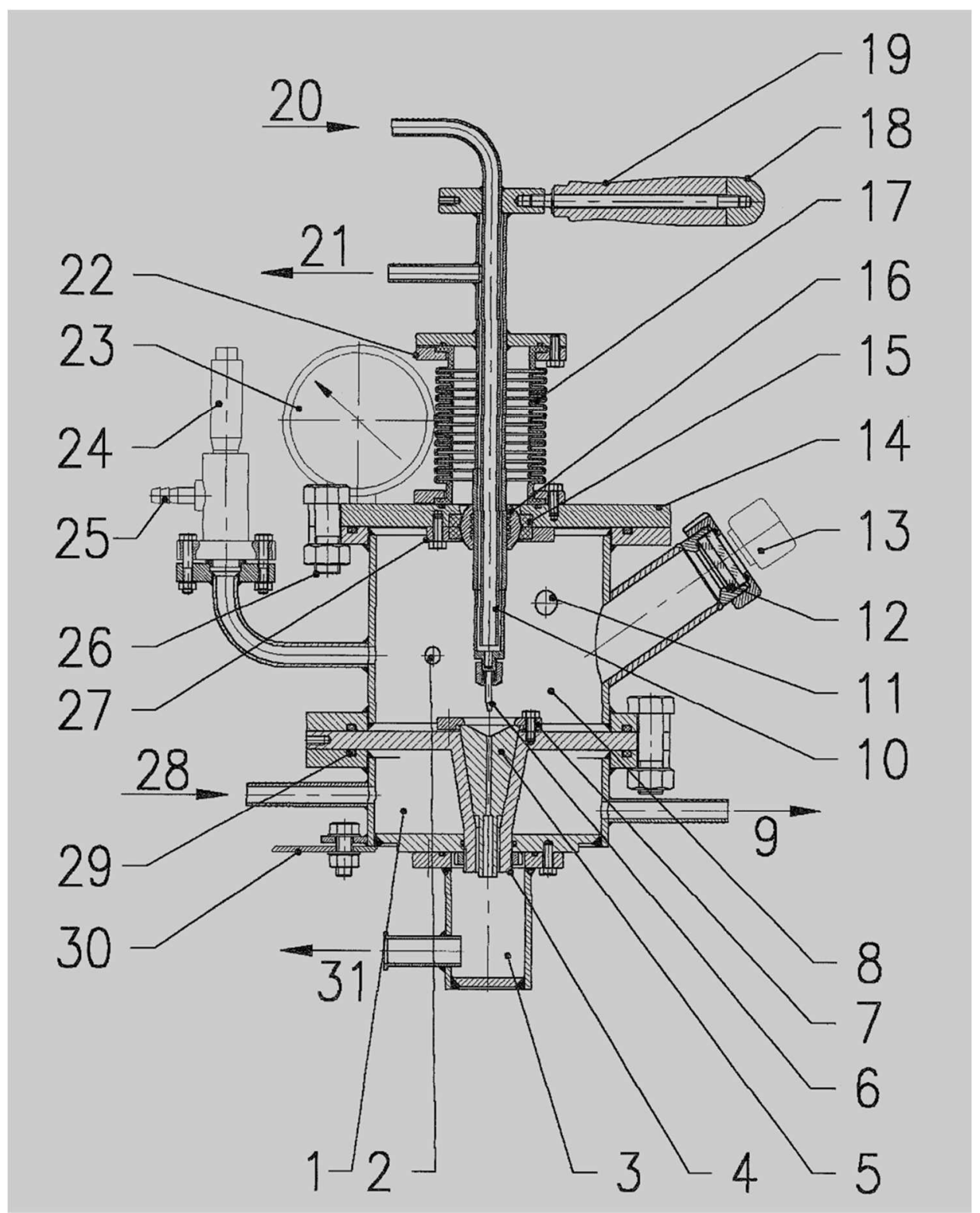

Fig. 6. The design of the arc furnace with an suction attachment composed of cooler (1), crucible housing (3) equipped with the vacuum outlet (31), cold crucible (4), divided cold crucible (5) and clamp ring (7), all fixed to the melting chamber (8)

As mentioned above, inside the suction attachment the divided cold crucible (5) is placed. This divided cold crucible is presented as a whole and in parts in Fig. 8. 


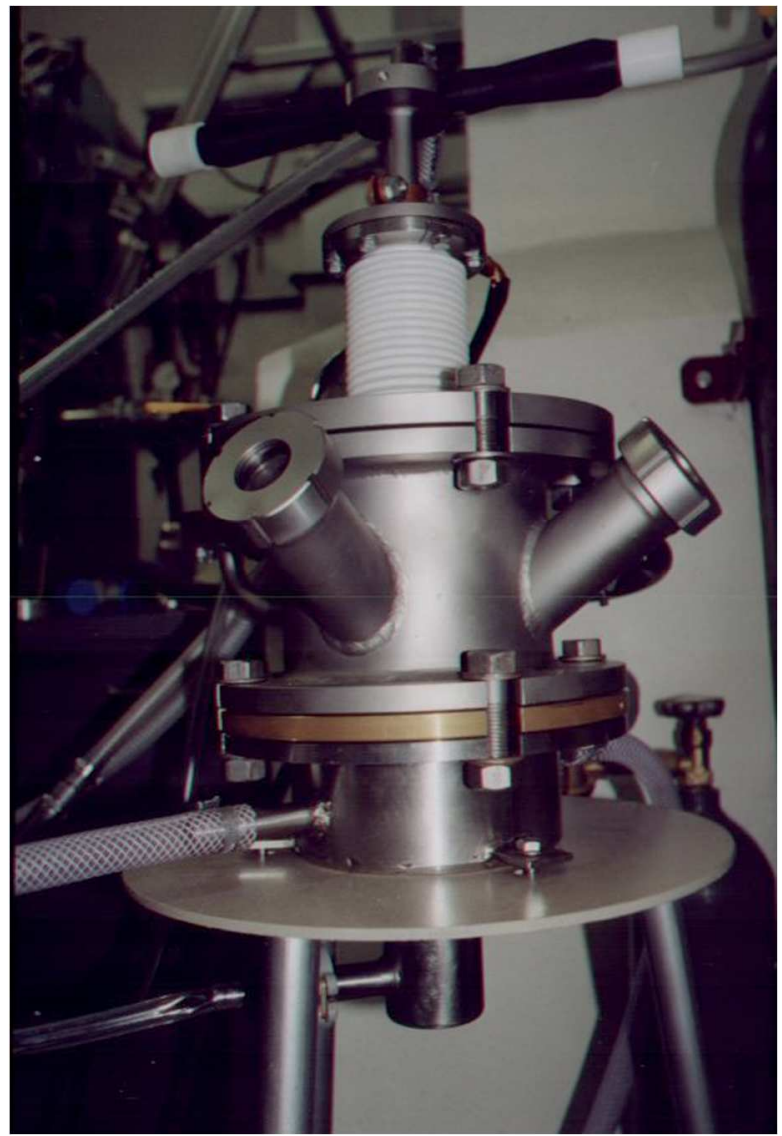

Fig. 7. The arc melting system with the suction attachment which is visible immediately above and under the circular table

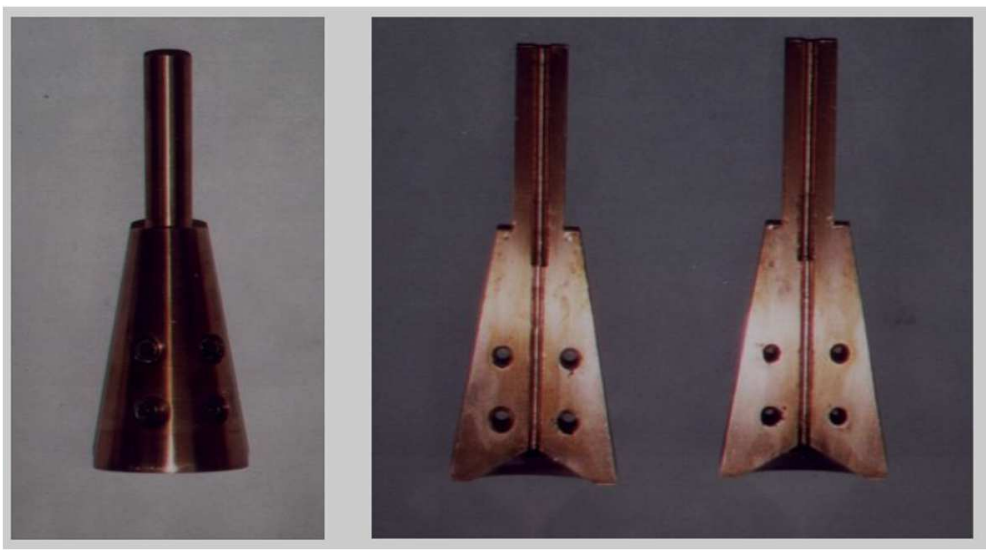

Fig. 8. The divided cold crucible as a whole (left) and in parts (right) 
In practice, divided cold crucibles with different diameters of holes are used. However these diameters are in the $0.5-3 \mathrm{~mm}$ range.

\section{A SYNTHESIS WITH THE SUCTION OF THE MELT}

The first steps of the synthesis procedure with the suction chamber are similar to those discussed above. Nevertheless, after complete melting of the starting materials, which are placed inside the hollow of the divided crucible (5), the rapid vacuum pumping of the crucible housing (3) (the suction chamber) is included shortly through the vacuum pump outlet (31) (Fig. 6), the drop melt is sucked into the hole of the divided cold crucible (5) and after that the melt is immediately solidified into the rod form (Fig. 9).

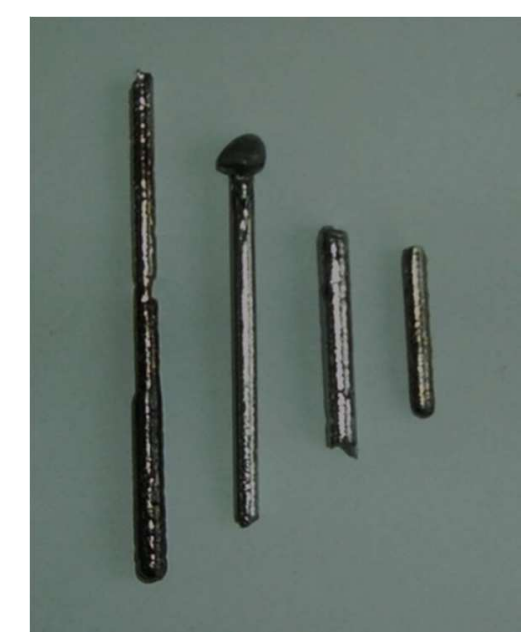

Fig. 9. Exemplary cast rods prepared using the furnace with the suction attachment

\section{SUMMARY}

The above described arc melting system and particularly its main component, the arc furnace with the non-contact ignition, has been used and tested many times. Hundreds of new crystallographically clean compounds, alloys and even ceramics have been synthesized for scientific and practical purposes (for instance [3,6,1113]). The clean crystal structure mainly follows the purity of the solidified melt of these materials.

The presented furnace and thus the arc melting system has a number of advantages. First of all, the arc system and especially the furnace is convenient and easy to operate. Here, it can be added that the applied power supply unit enables control of the arc current and thus control of the arc power used for 
melting [4]. The melting chamber can be easily disconnected before a cleaningup procedure using the side fast fittings (Figs 2, 3, 7). Vacuum- or air-tightness is maintained by the o-rings placed in circular u-grooves on particular parts of the melting chamber.

Two sight-glasses aimed at the middle of the cold crucible can be used for inspection of the melting process, for non-contact appreciation of the temperature of the melt or to light up the melting chamber inside. In order to protect ones vision the melting process must be observed using welding safety goggles with proper filter lenses. These must filter out harmful infra-red and ultra-violet rays emitted from the melting arc, and reduce visible light to a level which is sufficient to see the melting process without straining the eyes. Alternatively, the sight-glasses must be equipped with the cover windows composed of the proper filter lenses [7$10,14]$. Windows of the sight-glasses are easily disassembled in order to clean up the lenses.

Both the crucible housing close together with the crucible and the electrode tube with the tungsten end electrode are intensively cooled by the water system. The negative pole of the welder is connected by cable to the electrode tube to establish the electrically negative electrode, whereas the positive pole of the welder is connected by a second cable to the flange of the crucible housing to form the positive electrode from the crucible and the rest of the melting chamber. The isolating handles with the acorn nuts prevent electrical shock during melting and also during high voltage ignition. Nevertheless, during the melting procedure all welding safety rules should be fulfilled. Suitable shoes, protective apron and welding gloves must be used [7-10,14].

It can be emphasized, that the presented arc-melting system, well-tested in practice, can be treated as useful equipment in scientific or technological laboratories as well as factory equipment for a high-tech production on a small scale. The bigger arc melting system with non-contact ignition can of course be developed for a higher scale of production. Moreover, it can be mentioned that the next step for further studies is to test the microscopic metallurgical properties of the obtained ingots.

\section{Acknowledgements}

Supported partially by Polish Committee of Scientific Research, grant no. 4T08D03322. M. Proszowski and P. Stoch are acknowledged for valuable discussions.

\section{LITERATURE}

[1] Herget C., Domazer H.G., Methods for the production of rare earth - 3d metal alloys with particular emphasis on the cobalt alloys, Goldschmidt Informiert, 1975, Vol. 4/75, No. 35, pp. 3-33. 
[2] Bradshaw A.R., Fort D., A laboratory-scale arc furnace for melting volatile metals under elevated inert gas pressures, Rev. Sci. Instruments, 1992, Vol. 63, No. 11, pp. 5459-5463.

[3] Onak M., Pszczoła J., Otrzymywanie zwiąków międzymetalicznych ziemia rzadka metal przejściowy metoda syntezy $w$ tuku elektrycznym, Materiały XXVIII Szkoły Inżynierii Materiałowej, Kraków-Szczawnica 3-6 X 2000, Wyd. WMiIM AGH (2000)211 (in Polish).

[4] Spawalnicze źródto prądu TIGER 250 PROFI, Instrukcja instalacji i obstugi, BESTER S.A., Bielawa (in Polish).

[5] Tarflen, politetrafluoroetylen, (broszura) Zakłady Azotowe w Tarnowie-Mościcach (in Polish).

[6] Stoch P., Onak M., Pańta A., Pszczoła J., Suwalski J., Otrzymywanie i struktura krystaliczna związków międzymetalicznych $\mathrm{Dy}(\mathrm{Fe}$-Co-Al)2, Monografie IEA, Instytut Energii Atomowej, Otwock-Świerk 2002, Vol. 5 (in Polish).

[7] Kurbiel A., Elektrotermiczne urzadzenia tukowe, WNT, Warszawa 1988 (in Polish).

[8] Hauser. J., Podstawy elektrotermicznego przetwarzania energii, Zakł. Wyd. K. Domke, Poznań 1996 (in Polish).

[9] Dobaj E., Maszyny i urzqdzenia spawalnicze, WNT, Warszawa 1988 (in Polish).

[10] Minnick W.H., Prosser M.A., Gas Tungsten Arc Welding Handbook, Sixth Edition, The Goodheart-Willcox Company, Inc.,Tinley Park, IL 2016.

[11] Bednarski M., Chmist J., Pszczoła J., Crystal structure, electrical resistivity and Curie temperature of $\mathrm{Ho}\left(\mathrm{Mn}_{1-x} \mathrm{Fe}_{x}\right)_{2}$ and $\mathrm{Ho}\left(\mathrm{Co}_{1-x} \mathrm{Ni}_{x}\right)_{2}$ intermetallics, Journal of Magnetism and Magnetic Materials, 2013, Vol. 334, pp. 59-65.

[12] Onak M., Guzdek P., Stoch P., Chmist J., Bednarski M., Pańta A., Pszczoła J., Crystal structure and electrical resistivity studies of $G d\left(\mathrm{Fe}_{I_{-x} \mathrm{Co}} \mathrm{C}_{2}\right.$ intermetallics, Journal of Alloys and Compounds, 2007, Vol. 433, pp. 53-58.

[13] Onak M., Guzdek P., Pszczoła J., Stoch P., Jabłońska A., Suwalski J., A. Pańta, Crystal structure and Mössbauer effect studies of $G d\left(\mathrm{Mn}_{1-x} \mathrm{Fe} \mathrm{e}_{x}\right)_{2}$ and $\mathrm{Gd}\left(\mathrm{Fe}_{1-x} \mathrm{Co}_{x}\right)_{2}$ intermetallics, Nukleonika, 2007, Vol. 52, supp.l.

[14] www.lincolnelectric.com/en-gb/education-center/welding-safety; 02.06.2018.

\section{ZESTAW DO TOPIENIA W LUKU ELEKTRYCZNYM Z BEZKONTAKTOWYM ZAPŁONEM}

Topienie w łuku elektrycznym jest metodą szeroko używaną w fizyce materiałów, w ogólności w nauce o materiałach, jak również w metalurgii do syntezy nowych materiałów ze składników o wysokiej czystości. Z reguły łuk elektryczny jest używany do syntezy nowych materiałów z wysokotopliwych metali a nawet tlenków, gdyż łatwo jest uzyskiwana wysoka temperatura w tym procesie. W typowych metodach topienia łuk elektryczny jest zapalany przez krótki kontakt a następnie oddalenie elektrody od tygla na niewielką odległość. Taki kontaktowy zapłon może jednakże zanieczyścić końcówkę elektrody wolframowej i w następstwie obniżyć czystość otrzymanego wytopu w porównaniu ze składnikami wyjściowymi. W celu uniknięcia procedury kontaktowej i tym samym redukcji czystości w pracy jest zaproponowany zestaw do topienia $\mathrm{z}$ bezkontaktowym zapłonem łuku elektrycznego. Zestaw do topienia w łuku elektrycznym, projekt pieca, gotowy do użycia piec, proces topienia są przedstawione i dyskutowane. Dodatkowo jest przedstawiony piec łukowy z przystawką ssącą do otrzymywania wytopów w kształcie prętów. 
Czyste struktury krystaliczne znane z literatury, otrzymano dla wielu związków syntetyzowanych metodą łuku elektrycznego z bezkontaktowym zapłonem. Jakość struktur krystalicznych wynika głównie z utrzymania czystości materiałów podczas syntezy.

Słowa kluczowe: łuk elektryczny, zestaw do topienia, bezkontaktowy zapłon, projekt pieca, proces syntezy, przystawka ssąca, czystość materiałów

DOI: 10.7862/rf.2018.pfe.3

Received 15.06.2018

Accepted 12.09.2018 
